\title{
Patterns of N-CAM expression during myogenesis in Xenopus laevis
}

\author{
B. K. KAY ${ }^{1}$, L. M. SCHWARTZ ${ }^{1}$, U. RUTISHAUSER ${ }^{3}$, T. H. QIU ${ }^{2}$ and H. B. PENG ${ }^{2}$ \\ 'Department of Btology and ${ }^{2}$ Department of Anatomy, University of North Carolina at Chapel Hill. Chapel Hill, North Carolina 27514. \\ USA \\ ${ }^{3}$ Department of Developmental Genetics and Anatomy, Case Western University Medical School, Cleveland, Ohio 44016, USA
}

\section{Summary}

The neural cell adhesion molecule (N-CAM) is seen in the membrane of nerves and muscles from several vertebrate species. Using indirect immunofluorescence, we have examined the expression of this protein during embryonic and postembryonic myogenesis in the African clawed frog, Xenopus laevis. While good staining for $\mathrm{N}$-CAM was seen in neuronal tissues at all stages examined, no staining of embryonic muscle was observed, including both mononucleated and polynucleated myoblasts. In contrast, limb muscles formed at metamorphosis showed strong expression of $\mathrm{N}-\mathrm{CAM}$. The developing limb muscles eventually lose their $\mathrm{N}$-CAM, but will reexpress it dramatically when denervated. These observations suggest that myogenesis programs executed at different stages of development can display distinct patterns of N-CAM expression.

Key words: N-CAM, myogenesis, Xenopus, expression.

\section{Introduction}

The neural cell adhesion molecule (N-CAM) is thought to play a critical role in neurogenesis and myogenesis in all vertebrate species examined to date (Edelman, 1984; Rutishauser, 1984). In chicken embryos, N-CAM is expressed over a significant proportion of the surface of the gastrula embryo, although as development progresses, N-CAM becomes restricted to both developing muscles and nerves (Edelman et al. 1983; Edelman, 1986). In mouse embryos, N-CAM can be found on developing muscles and nerves (Rieger et al. 1985). The expression of this molecule on differentiating muscle cells is thought to be a requisite component of synaptogenesis (Grumet et al. 1982; Rutishauser et al. 1983; Covault \& Sanes, 1985).

In the amphibian, Xenopus laevis, N-CAM expression has been shown to be unusually restricted to neural cells during embryogenesis. Immunofluorescence staining of frog embryos with rabbit polyclonal antibodies directed against Xenopus N-CAM has shown that the protein is not expressed until late gastrula stage (Balak et al. 1987). During development of the early embryo, N-CAM is detectable only on developing neural cells, with a transient expression on somitic cells. Due to its exquisite neural specificity, expression of the N-CAM protein is an early marker for the process of neural induction (Jacobson \& Rutishauser, 1986). Recently, several cDNAs for Xenopus N-CAM have been identified and used in evaluating the levels of N-CAM mRNA during development (Kintner \& Melton, 1987). From RNA blots and in situ hybridization experiments, it appears that N-CAM mRNA accumulates in neural tissue but not in developing somites. Thus from published reports it initially appeared that Xenopus development differs from that of birds and mammals in not expressing N-CAM in myotomal muscles.

In this paper, we follow the expression of $\mathrm{N}$-CAM during both embryonic and postembryonic myogenesis in Xenopus. We find that no embryonically derived muscle cell expressed $\mathrm{N}$-CAM. In contrast, limb muscles formed at metamorphosis displayed strong N-CAM expression.

\section{Materials and methods}

\section{Embryos and antibodies}

Tadpoles at various stages of development were fixed, embedded in paraffin and sectioned as described elsewhere (Kay et al. 1987). Embryos were staged according to Nieuwkoop \& Faber (1967). Sections $(10 \mu \mathrm{m})$ were stained with either the 4D mouse monoclonal antibody (Frelinger 
\& Rutishauser, 1986; Watanabe et al. 1986) or a rabbit polyclonal antibody (Balak et al. 1987) directed against frog $\mathrm{N}-\mathrm{CAM}$ and then visualized with a rhodamine-labelled, goat secondary antibody (Jackson Laboratories, Avondale, PA). Whole-mount preparations were fixed, permeabilized, stained and examined according to Schwartz \& Kay (1988). For some experiments, rhodamine-labelled phalloidin was used to stain all musculature (Molecular Probes, Inc., Eugene, OR).

\section{Immunoblots}

Various tissues were homogenized with a Tissuemizer (Tekmar, Cincinnati, OH) in PBS with $0.5 \%$ NP40, $1 \mathrm{~mm}$ EDTA and $100 \times 10^{3} \mathrm{i}$.u. $\mathrm{ml}^{-1}$ aprotinin. The extracts were then boiled in the presence of loading buffer and resolved by electrophoresis in a $7 \%$ SDS-polyacrylamide gel (Laemmli, 1970). The proteins were then transferred electrophoretically to nitrocellulose filters, and the N-CAM detected with a polyclonal rabbit antibody and ${ }^{125}$ I-labelled protein A (Towbin et al. 1979).

\section{Preparation of in vitro cultures}

Myotomal muscle cells, which develop into tail musculature in vivo, were isolated from stage-20 to -22 embryos and cultured according to published protocols (Peng \& Nakajima, 1978). Dissociated muscle cells were also prepared from the tails of stage- 50 tadpoles by anaesthetizing the animals in tricaine methylsulphonate (MS222), excising the tails, removing the skin and treating the tissue with $3 \mathrm{mg} \mathrm{ml}^{-1}$ collagenase in frog Ringer's solution for $2-3 \mathrm{~h}$. Single muscle cells were then isolated by gentle trituration with a Pasteur pipette.

Myoblast cultures of developing limbs of Xenopus larvae were prepared as follows. Limbs of anaesthetized stage-55 tadpoles were excised in frog Ringer's solution. After the skin and bone were removed, the limbs were teased into small pieces and incubated in $\mathrm{Ca}^{2+}, \mathrm{Mg}^{2+}$-free Ringer's solution containing $0.4 \mathrm{~mm}$-EDTA, $2.5 \mathrm{mg} \mathrm{ml}^{-1}$ trypsin and $2 \mathrm{mg} \mathrm{ml}^{-1}$ collagenase for $1 \mathrm{~h}$ at room temperature. Then the tissue pieces were triturated and the cells dissociated from the treated tissue were recovered by gentle centrifugation in a table-top centrifuge. The cells were then plated onto coverglass squares and cultured in $50 \mathrm{~L}-15$ (Leibovitz) medium (GIBCO, Grand Island, NY), containing $5 \%$ fetal bovine serum and $10 \mathrm{~mm}-$ Hepes $(\mathrm{pH} 7 \cdot 4)$ at $22^{\circ} \mathrm{C}$.
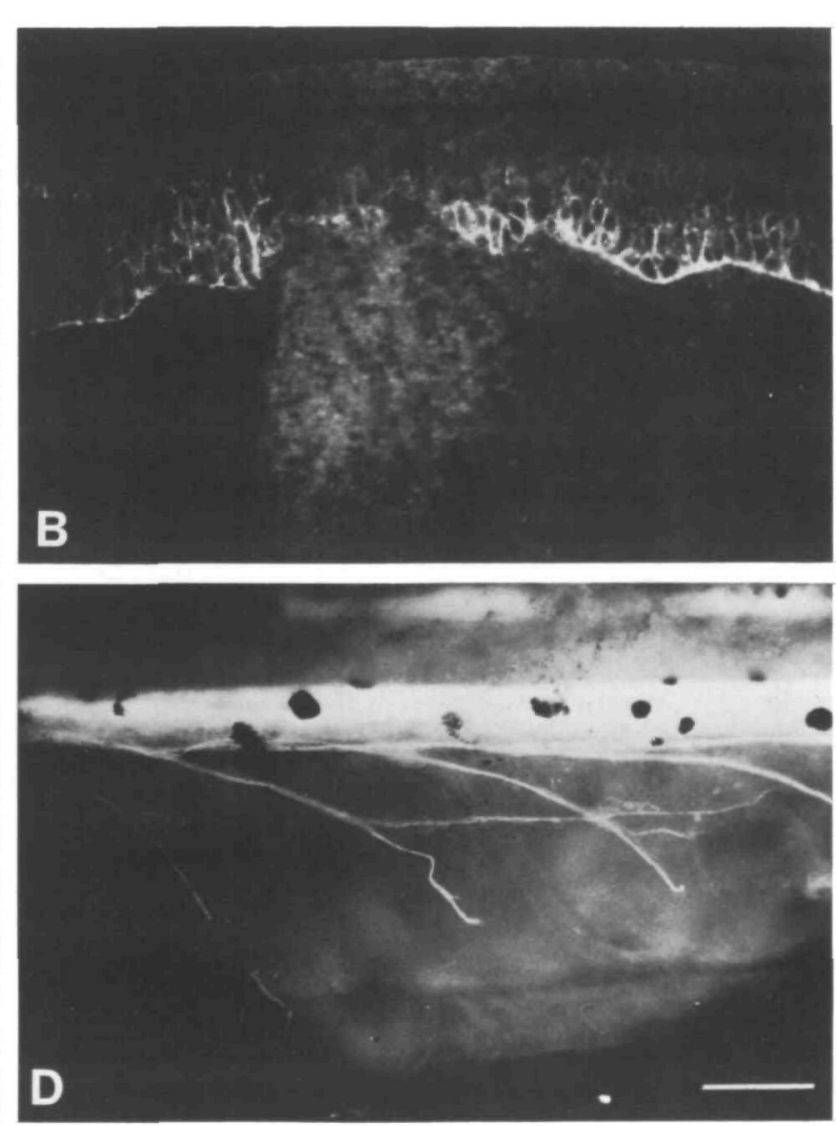

Fig. 1. During the formation of the tail, N-CAM is expressed solely on neural tissues in Xenopus embryos. A shows a phase-contrast image of a longitudinal cross section of a stage-22 embryo. B is the corresponding immunofluorescence image obtained with rabbit N-CAM antibodies and goat anti-rabbit Ig antibodies linked to FITC. The cell membranes of the neural tube are labelled, whereas the mononucleated muscle cells arranged in somites are not. C shows an $\mathrm{N}$-CAM immunofluorescence staining of a stage- 25 embryo. The level of background fluorescence is high in $\mathrm{B}$ and $\mathrm{C}$ due to the autofluorescence of yolk. D shows N-CAM immunofluorescence staining of a whole-mount strip of a stage-42 tadpole tail. The pigmented cells of the neuroepithelium do not stain, nor do the myotomal muscles separating each set of axons. $\mathrm{N}$, row of nuclei. Bar, $120 \mu \mathrm{m}$ in $\mathrm{A}-\mathrm{C}$ and $100 \mu \mathrm{m}$ in $\mathrm{D}$. 
After a culture period of 2-3 days, myotubes with 2-20 nuclei could be detected in these cultures. In some instances, the nuclei were stained in fixed preparations with 4',6-diamidino-2-phenyl-indole (DAPI; Sigma Chemical Co., St Louis, MO).

Explants of neural tubes were cultured as previously described (Peng et al. 1987). In short, neural tubes were removed from the excised neural tube, somite and the notochord complex of stage-22 to -25 embryos following a brief collagenase treatment. The tubes were then cut into pieces $0.55 \mathrm{~mm}$ in length and cultured onto polylysinecoated coverglasses in Steinberg's solution (Hamburger, 1960) supplemented with $10 \%$ L-15 medium, $1 \%$ fetal bovine serum, $1 \%$ garamycin (Schering Corp., Kenilworth, $\mathrm{NJ}$ ), and $4 \mu \mathrm{g} \mathrm{ml}^{-1}$ laminin (Bethesda Research Laboratories, Gaithersburg, MD)

Cultures were labelled with N-CAM antibody followed by fluorescein-conjugated goat anti-rabbit antibody either in the living state or after fixation. Cells were fixed either with Luther's fixative $(0.25 \mathrm{~mm}$-paraformaldehyde, $80 \mathrm{~mm}$ cyclohexylamine, $10 \mathrm{~mm}$-EGTA, $10 \mathrm{~mm}$-Pipes, $10 \mathrm{~mm}$ $\mathrm{MgCl}_{2}$, $\mathrm{pH} 6.5$; P. W. Luther, in preparation) or Bouin's fixative (Humason, 1979). Consistent results were obtained with both of these methods. The acetylcholıne receptors on muscle cells were examined by labelling living cells with tetramethylrhodamine-conjugated (R-BTX; Molecular Probes, Inc.).

\section{Results}

\section{Expression of N-CAM in developing tadpoles}

Using the polyclonal antibodies to frog N-CAM, we observed strong staining of $\mathrm{N}-\mathrm{CAM}$ in neuronal tissue, but none on the somites of neurula-staged Xenopus embryos. These observations are in good agreement with recently published observations (Balak et al. 1987; Kintner \& Melton, 1987). Fig. 1A shows a phase-contrast micrograph of a sagittal section through a stage-22 larva, where the rows of nuclei $(\mathrm{N})$ define the centre of each myotomal segment. When this same section was stained for N-CAM and examined by epifluorescence (Fig. 1B), only the cell membranes in the neural tube were stained. At stage $25,3 \cdot 5 \mathrm{~h}$ later, coincident with the innervation of the muscles (Blackshaw \& Warner, 1976), the neural tube and outgrowing neuronal processes were stained (Fig. 1C). At this level of resolution, we cannot determine if there is any postsynaptic expression of $\mathrm{N}$-CAM, but this question is addressed with the in vitro experiments described below. The specificity of staining is revealed in Fig. 1D, where a whole mount from a stage- 41 animal is examined. Here the central nervous system and the segmental nerves stain prominently, but the myotomal muscles are immunonegative.

Most vertebrate muscles are formed from myoblasts that fuse together to generate multinucleated myotubes and, subsequently, muscle fibres. In con- trast, the myotomes of Xenopus are produced from large mononucleated myocytes which become fully functional both in receiving innervation and in contractility in the absence of cell fusion (Hamilton, 1969). They do undergo fusion with satellite cells and enlarge later in development (Muntz, 1975). These cells degenerate ultimately during metamorphosis when the tail is reabsorbed. We sought to determine whether the lack of N-CAM staining is due to these unique developmental features of the myotomal muscles. To answer this question, another muscle in the Xenopus larva, the mylohyoid (intermandibular) muscle was examined. Embryonically, it is formed by the fusion of myoblasts (Deuchar, 1975). This muscle is a flattened sheet of multinucleated fibres, which resides at the base of the throat and survives through metamorphosis (Deuchar, 1975). In whole mounts of tadpole heads, this muscle was easily discernible by staining with rhodamine-labelled phalloidin
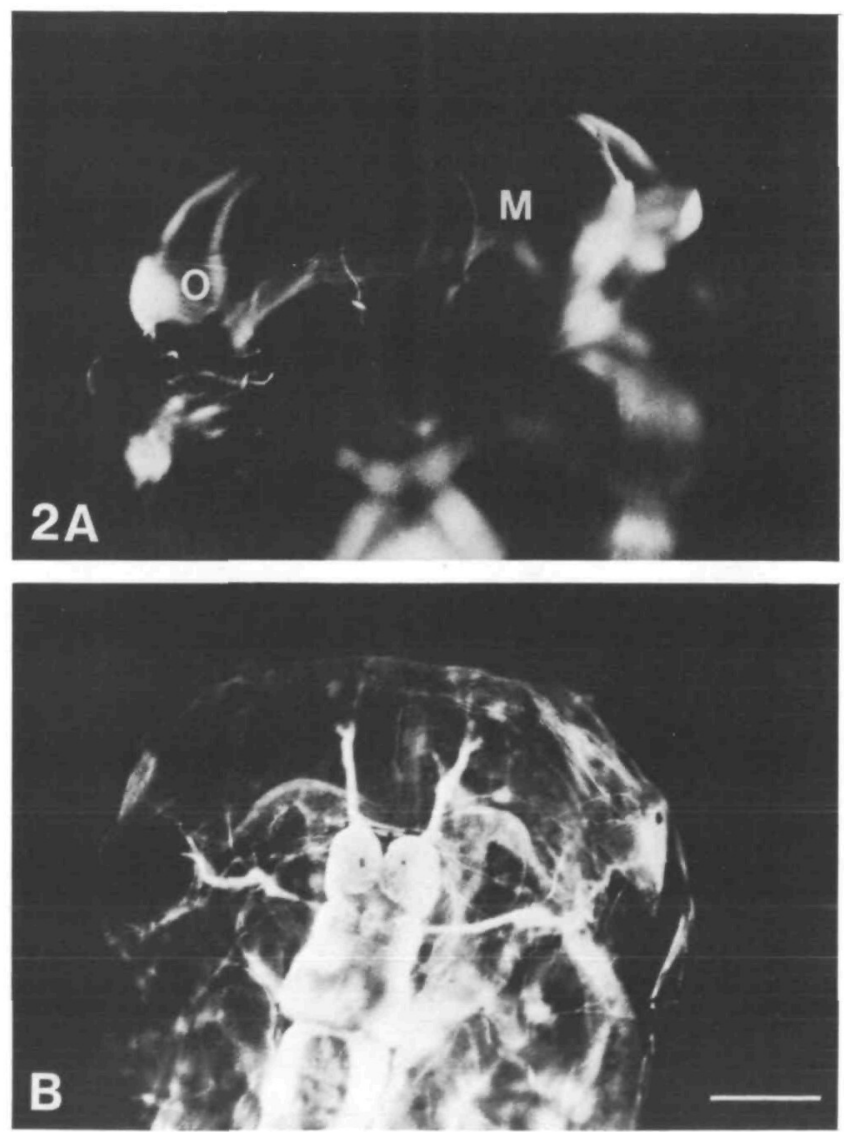

Fig. 2. N-CAM expression is neural-specific in tadpole heads. $\mathrm{A}$ is the fluorescent image of a stage- 41 tadpole stained with rhodamine-labelled phalloidin. In this ventral view, the mylohyoid muscle (M) and ocular muscle (O) groups stain strongly. B displays the $\mathrm{N}$-CAM antibody immunofluorescence staining of a comparably staged tadpole whole-mount preparation. The ventral side of the head is shown, with bright staining of the brain, and the optic and olfactory nerves. Bar, $500 \mu \mathrm{m}$. 

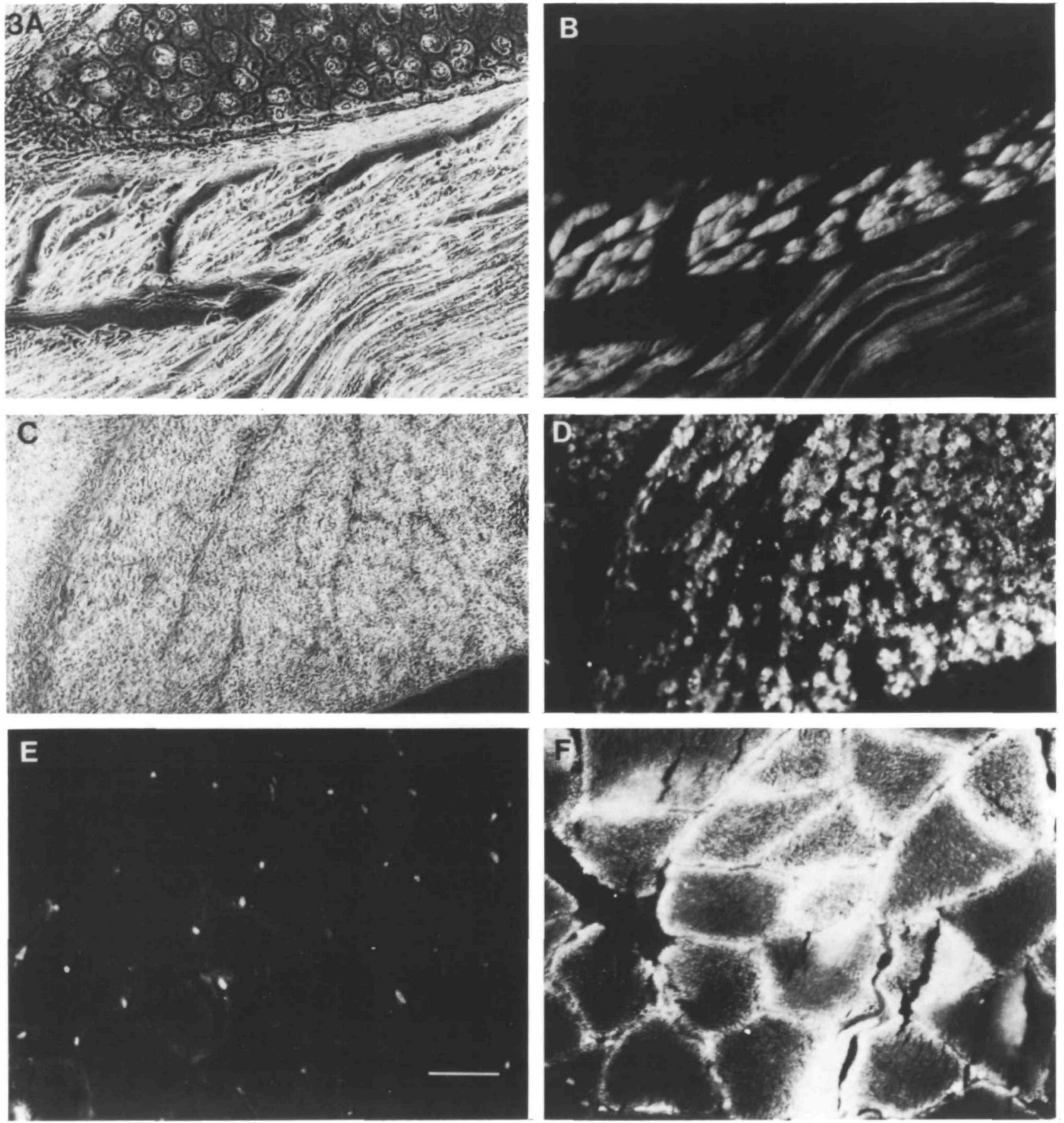

Fig. 3. N-CAM is expressed on the hindlimb muscles of tadpoles and on adult leg muscles after denervation. A shows a cross section of a hindlimb of a stage- 55 tadpole in phase contrast, and B shows the immunofluorescence staining of the same section obtained with the monoclonal antibody 4D. Note the strong staining of the muscle fibres with N-CAM antibodies. $\mathrm{C}$ is the phase-contrast image of a hindlimb muscle of a comparably staged tadpole, and $\mathrm{D}$ is the staining pattern obtained with polyclonal anti-frog N-CAM antibodies. E-F display the N-CAM immunofiuorescence staining of gastrocnemius muscles from the same adult frog with polyclonal anti-frog N-CAM antibodies; $E$ is from the intact limb and $\mathrm{F}$ is the contralateral leg 4 days after denervation. The bright spots in $\mathrm{E}$ are autofluorescing red blood cells. Bar, $135 \mu \mathrm{m}$. 
(Fig. 2A). However, this muscle was immunonegative when stained for N-CAM (Fig. 2B). Mylohyoid muscles were examined at several stages of larval development, and only the nerve running over its surface and the neuromuscular junctions were ever stained (data not shown). Thus, the lack of N-CAM expression in the myotomal muscle is shared by a very different embryonically derived muscle.

One attractive feature of amphibian development is that the animals undergo a second phase of de novo muscle differentiation at metamorphosis with the formation of the limbs. The section shown in Fig. 3A and $\mathrm{B}$ shows muscle and bone from the thigh of a stage-55 tadpole. For this experiment, the 4D mouse monoclonal antibody (IgG), which recognizes a cytoplasmic determinant of the chicken $180 \times 10^{3} M_{\mathrm{r}}$ N-CAM species (Frelinger \& Rutishauser, 1986; Watanabe et al. 1986), was used to stain the musculature. In cross sections, the staining with the monoclonal antibody was restricted to the periphery of the muscle fibres, suggesting that the antigen may be membrane bound. Polyclonal antibodies to frog $\mathrm{N}$-CAM likewise stained many muscle fibres (Fig. 3C,D). Interestingly, not all muscle fibres stained equally well, suggesting either a spatial or temporal pattern of regulated N-CAM expression by muscle cells (Fig. 3D). Developing muscles in the forelimbs of tadpoles revealed a comparable pattern of $\mathrm{N}$-CAM expression (data not shown).

After metamorphosis to the adult, the amount of $\mathrm{N}$-CAM staining in the limb musculature was greatly reduced (Fig. 3E). To determine if the expression of $\mathrm{N}$-CAM was under neuronal influence, as has been described for mouse and rat (Covault \& Sanes, 1986; Sanes, 1986), we severed the sciatic nerve of an adult frog, thus denervating the gastrocnemius muscle. We examined by immunofluorescence the denervated muscle after 4 days (Fig. 3F) and compared it to the contralateral, unmanipulated gastrocnemius muscle from the same individual (Fig. 3E). As can be readily observed, the degree of N-CAM immunoreactive material increased dramatically after denervation.

\section{Molecular characterization of the N-CAM antigens}

As stated in the Materials and methods, most of the indirect immunofluorescence data shown in this study were generated with a rabbit polyclonal antibody generated against frog N-CAM (Balak et al. 1987). To validate that the antigens recognized in these photographs reflect the distribution of authentic N-CAM, a representative Western blot is shown in Fig. 4. In lane $A$, a chicken embryo brain extract was used as a control to reveal the previously described N-CAM polypeptide species of 180,140 and $120 \times 10^{3} M_{\mathrm{r}}$, respectively (Rutishauser, 1984; Edelman, 1986). Lane B displays the presence of the same three

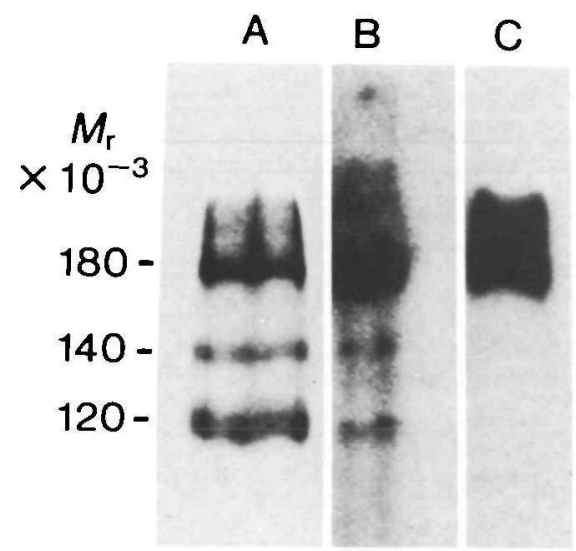

Fig. 4. Western blots of Xenopus embryonic tissues with $\mathrm{N}$-CAM antibodies. Various samples were homogenized in extraction buffer, electrophoresed in a $7 \%$ SDSpolyacrylamide gel, blotted and reacted with the rabbit anti-frog N-CAM antibodies. Lane A contains chick embryonic brain (E15), B developing limbs of a stage-55 Xenopus tadpole, and $\mathrm{C}$ brain of a stage-55 tadpole. Sizes of the major reactive polypeptide chains are $M_{\mathrm{r}} \times 10^{-3}$.

N-CAM species in an extract of Xenopus developing leg muscle. The material examined in lane $\mathrm{C}$ is from tadpole brain and shows that only the $180 \times 10^{3}$ species appears to be expressed by this tissue. This observation is in good agreement with Sunshine et al. (1987). No other bands above background were evident on Western blots. These data suggest that our polyclonal antibody recognized authentic N-CAM in sectioned material.

\section{Myotomal cells in culture}

The results described above show that the myotomes of Xenopus do not express N-CAM except at regions of innervation. To determine whether or not this was a presynaptic or postsynaptic labelling, we examined the appearance of N-CAM on primary cultures of myotomal muscle cells. These cells do not undergo fusion in tissue culture and remain mononucleated. As shown in Fig. 5A and B, these muscle cells did not demonstrate detectable levels of N-CAM on their surfaces. N-CAM was likewise absent from the spontaneously formed, acetylcholine receptor clusters ('hot spots') as shown by R-BTX labelling (Fig. 5C,D). This is in sharp contrast to the bright staining of neurones and neuronal processes in explant cultures of Xenopus spinal cord (Fig. 5E).

To further assess the localization of N-CAM at the neuromuscular junction, we examined myotomal cells dissociated from the tail musculature of stage- 50 tadpoles. The muscle cells at this stage are multinucleated, as determined by DAPI fluorescence (not shown). At the ends of these isolated cells are patches of acetylcholine receptors, which mark the sites of the postsynaptic membrane (Fig. 5F). Double staining 

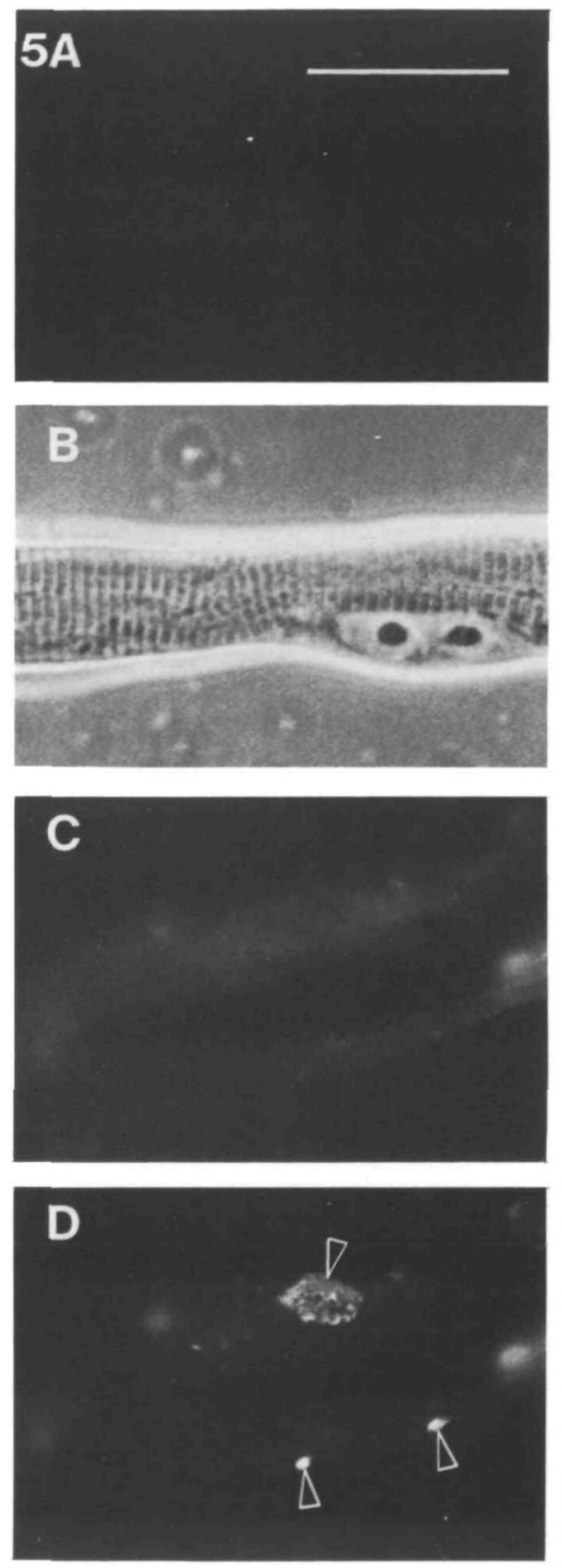
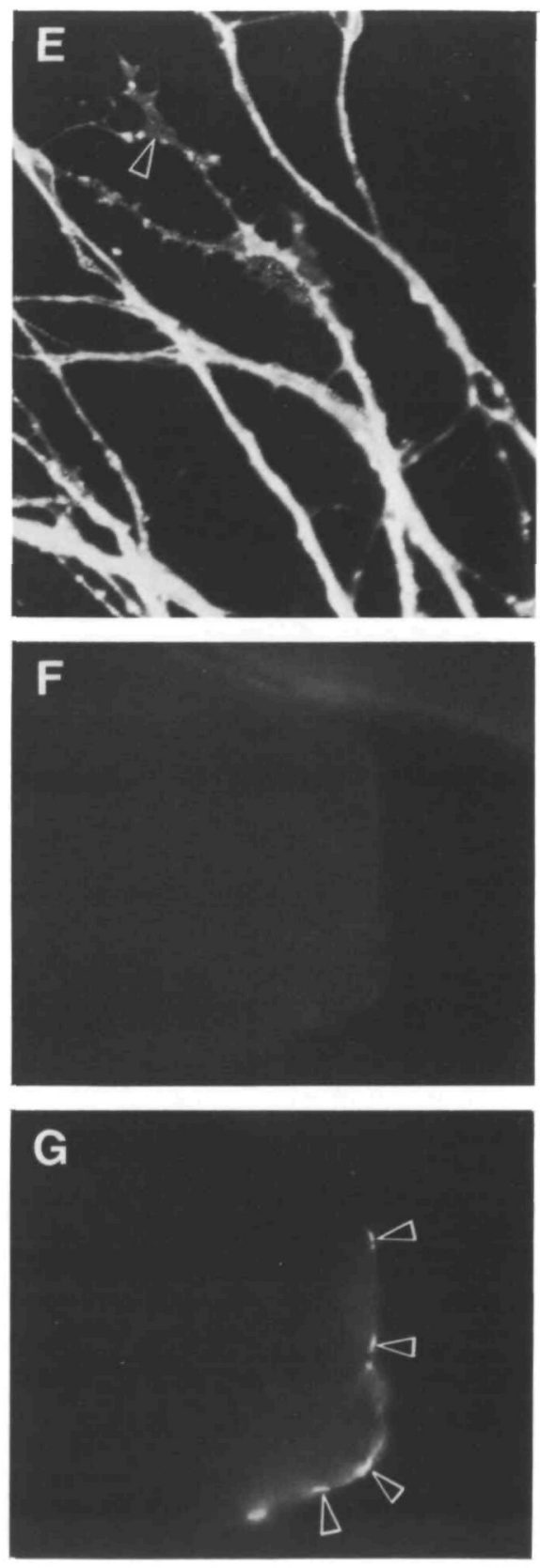

Fig. 5. Lack of N-CAM expression in cultured Xenopus myotomal muscle cells. Tail muscle cells from stage-22 embryos were cultured and reacted in the living state with N-CAM antibodies and FITCconjugated secondary antibodies (A), or examined by phasecontrast microscopy (B). Cells were also double stained with $\mathrm{N}$-CAM antibodies (C) and R-BTX (D); the spontaneously formed acetylcholine receptor clusters (marked with arrowheads in D) do not react with N-CAM antibodies. Neurites and growth cones (arrowhead) from neural tube explants, on the other hand, react quite well with $\mathrm{N}-\mathrm{CAM}$ antibodies (E). Muscle cells from stage-50 tadpoles were also examined for N-CAM expression after dissociation from the tail musculature. After dissociation, these cells were immediately fixed and processed for binding of N-CAM antibodies (F) or R-BTX (G). Note the lack of N-CAM at the postsynaptic acetylcholine receptor clusters, marked by arrowheads in $\mathrm{G}$, as well as along the extrajunctional sarcolemma. Bar, $30 \mu \mathrm{m}$. with N-CAM antibody and R-BTX show that both the postsynaptic and the extrasynaptic membranes were devoid of N-CAM expression (Fig. 5G).

Myoblasts and myotubes of skeletal muscle in culture We also examined skeletal muscle cells from the developing limbs of tadpoles after culturing in vitro. The myoblasts were identified by their long, spindleshaped outline and uniform R-BTX staining (Fig. 6B,C). When the cells were reacted with $\mathrm{N}$-CAM antibodies, the myoblasts always stained positively (Fig. 6A). In the cultures, myoblasts often fused into myotubes, as seen by DAPI staining of the nuclei (Fig. 6F). These myotubes also revealed strong staining with both N-CAM antibodies and R-BTX
(Fig. 6D,E), although non-muscle cells did not stain with either reagent (Fig. 6A-F). Control cultures stained with preimmune serum always had greatly reduced fluorescein fluorescence levels when compared to N-CAM-stained preparations (Fig. 6G-I).

\section{Discussion}

From immunofluorescence staining of both in vivo and in vitro preparations, we have shown that the expression of N-CAM in embryonically and postembryonically derived muscle cells is quite different in Xenopus. The pattern of N-CAM expression in the 

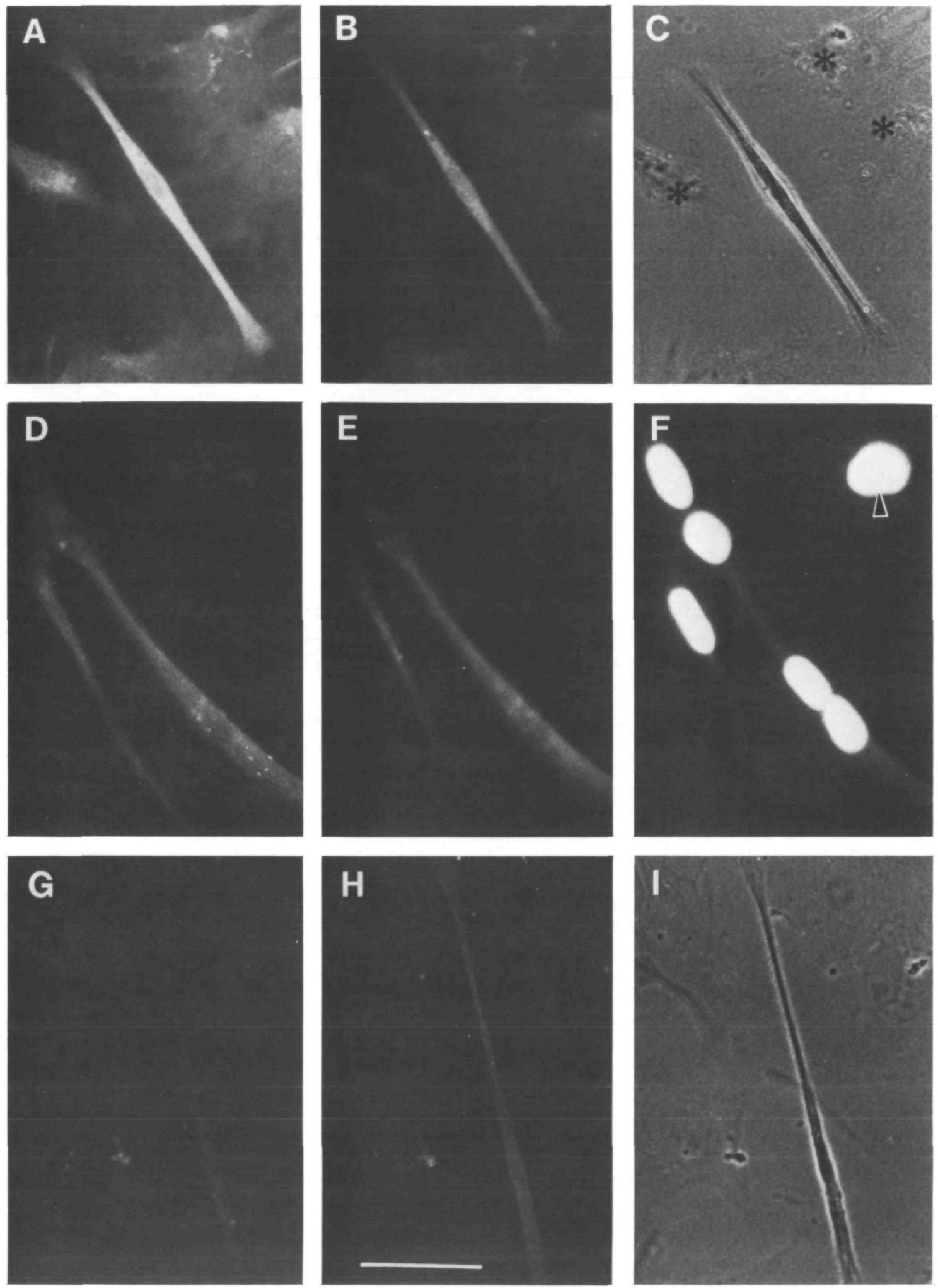

Fig. 6. N-CAM expression on cultured muscle cells from developing limb musculature of Xenopus. Left column: immunofluorescence staining for N-CAM; middle column: R-BTX staining to show the presence of acetylcholine receptors: right column: phase-contrast image (C,I) or DAPI staining (F). A-C shows a mononucleated myoblast and several fibroblasts (asterisks). D-F shows a developing myotube with four nuclei, a myoblast and a fibroblast (arrowhead). G-I shows a myoblast stained with preimmune serum $(\mathrm{G})$ or R-BTX $(\mathrm{H})$, and the corresponding phasecontrast image (I). Bar, $40 \mu \mathrm{m}$. 
postembryonically derived skeletal muscle is consistent with the previously published results for mammalian and avian systems (Thiery et al. 1982; Tosney et al. 1986; Covault \& Sanes, 1985; Duband et al. 1987). Moreover, the presence of both $\mathrm{N}$-CAM-expressing and -nonexpressing muscle cells in the developing hindlimb is similar to the pattern seen in musculature for developing chick hindlimbs (Tosney et al. 1986).

The general lack of N-CAM staining of embryonic muscles in Xenopus is remarkable. It cannot be due to the fact that the myotomal cells are mononucleated (Hamilton, 1969; Muntz, 1975) or that these cells degenerate during metamorphosis, since the mylohyoid muscle, which is composed of multinucleated cells and survives to adulthood, is immunonegative as well. The absence of the N-CAM molecule on larval muscles indicates that N-CAM is not likely to have a prominent function in their formation or innervation. Moreover, we cannot detect N-CAM at the postsynaptic membrane of Xenopus embryonic muscles where acetylcholine receptors are clustered, in contrast to the muscles of other animal systems which have N-CAM at their postsynaptic surfaces (Covault \& Sanes, 1985; Rieger et al. 1985). Nevertheless, we cannot rule out a minor role for N-CAM on Xenopus myotomal muscles, as a minor, transient expression of N-CAM has been reported on developing Xenopus muscle cells (Balak et al. 1987).

Several lines of evidence suggest that the patterns of immunofluorescent staining described in Results reflect the true distribution of N-CAM. First, neuronal tissue stained in all histological preparations, independent of developmental stage. Therefore, the lack of staining by embryonic muscles is not an artifact due to tissue preparation. Second, the polyclonal and monoclonal antibodies against N-CAM reacted with developing limb muscle. Given that the polyclonal antibody recognized the well-characterized 180,140 and $120 \times 10^{3} M_{\mathrm{r}} \mathrm{N}$-CAM species on Western blots, we feel that the antigen recognized in our immunofluorescence experiments is authentic N-CAM.

The significant expression of N-CAM in the developing limb muscles suggests that this molecule may mediate the nerve-muscle interaction in postembryonically derived muscles of Xenopus. In adults, these muscles have very little N-CAM and the limb bud muscles appear to have diminished expression shortly after their innervation (Jacobson, 1987). Recently, it has been shown that rodent adult muscles can reexpress N-CAM to high, embryo-like levels after denervation or paralysis (Covault \& Sanes, 1986; Sanes et al. 1986). Presumably, this reexpression is important in reestablishing proper nerve-muscle interactions. The adult frog gastrocnemius muscle also appears capable of such a response after denervation. This is in contrast to the tadpole myotomal muscles which do not express $\mathrm{N}-\mathrm{CAM}$, even when grown alone in tissue culture or after tubocurare-induced paralysis (Schwartz \& Kay, data not shown).

Recently, Bixby et al. (1987) have shown that axonal growth on muscle surfaces depends on the presence of cell adhesion molecules (CAMs), such as $\mathrm{N}$-CAM and neural $\mathrm{Ca}^{2+}$-dependent CAM, as well as molecules in the extracellular matrix. Suppression of any one molecule with antibodies had only a small effect on neurite outgrowth, but a suppression of all these molecules inhibits growth. Thus, N-CAM is but one of a class of molecules used by the developing nerve and muscle in their mutual interaction. Our study suggests that during embryonic development in Xenopus, this interaction is dominated by molecules other than N-CAM. This differential expression of $\mathrm{N}$-CAM during the formation of Xenopus muscles makes the animal particularly suitable for examining the comparative role of this molecule in myogenesis and synaptogenesis.

We acknowledge the photographic assistance of Susan Whitfield and the technical help of Holly MacArthur. This work was supported by grants from the March of Dimes (5-576) and American Cancer Society (CD-253) to B.K.K., the North Carolina Biotechnology Program and American Cancer Society (IN-15-29) to L.M.S., and the National Institutes of Health to U.R. and (NS-23583) to H.B.P.

\section{References}

Balak, K., Jacobson, M., Sunshine, J. \& Rutishauser, U. (1987). Neural cell adhesion molecule expression in Xenopus embryos. Devl Biol. 119, 540-550.

Bixby, J. L., Pratt, R. S., Lilien, J. \& Reichardt, L. F. (1987). Neurite outgrowth on muscle cell surfaces involves extracellular matrix receptors as well as $\mathrm{Ca}^{2+}$. dependent and -independent cell adhesion molecules. Proc. natn. Acad. Sci. U.S.A. 84, 2555-2559.

Blackshaw, S. \& Warner, A. (1976). Onset of acetylcholine sensitivity and endplate activity in developing myotome muscles of Xenopus. Nature, Lond. 262, 217-218.

Covault, J. \& Sanes, J. R. (1985). Neural cell adhesion molecule (N-CAM) accumulates in denervated and paralyzed skeletal muscle. Proc. natn. Acad. Sci. U.S.A. 82, 4544-4548.

Deuchar, E. M. (1975). Xenopus: the South African Clawed Frog. pp. 33-37. London: John Wiley and Sons.

Duband, J.-L., Dufour, S., Hatta, K., Takeichi, M. \& Edelman, G. M. (1987). Adhesion molecules during somitogenesis in the avian embryo. J. Cell Biol. 104, 1361-1374.

Edelman, G. M. (1984). Modulation of cell adhesion during induction, histogenesis and perinatal 
development of the nervous system. A. Rev. Neurosci. 7, 339-377.

Edelman, G. M. (1986). Cell adhesion molecules in the regulation of animal form and tissue pattern. A. Rev. Cell Biol. 2, 81-116.

Edelman, G. M., Gallin, W. J., Delouvee, A., Cunningham, B. A. \& Thiery, J.-P. (1983). Early epochal maps of two different cell adhesion molecules. Proc. natn. Acad. Sci. U.S. A. 80, 4384-4388.

Frelinger, A. L., III \& Rutishauser, U. (1986). Topography of N-CAM structural and functional determinants. II. Placement of monoclonal antibody epitopes. J. Cell Biol. 103, 1729-1737.

Grumet, M., Rutishauser, U. \& Edelman, G. M. (1982). Neural cell adhesion molecule is on embryonic muscle cells and mediates adhesion to nerve cells in vitro. Nature, Lond. 295, 693-695.

Hamburger, V. (1960). A Manual of Experimental Embryology. p. 36. Chicago: University of Chicago Press.

HamiLton, L. (1969). The formation of somites in Xenopus. J. Embryol. exp. Morph. 22, 253-264.

Humason, G. L. (1979). Animal Tissue Techniques. p. 24. 4th ed. San Francisco: W. H. Freeman \& Co.

JACOBSon, M. (1987). Neural cell adhesion molecule (NCAM) expression in Xenopus embryos during formation of central and peripheral neural maps. In The Making of the Nervous System. pp. 128-147. Oxford: Oxford University Press.

JACOBSON, M. \& Rutishauser, U. (1986). Induction of neural cell adhesion molecule (N-CAM) in Xenopus embryos. Devl Biol. 116, 524-531.

Kay, B. K., Shah, A. J. \& Halstead, W. E. (1987). Expression of the $\mathrm{Ca}^{2+}$-binding protein, parvalbumin, during embryo development of the frog, Xenopus laevis. J. Cell Biol. 104, 841-847.

Kintner, C. R. \& Melton, D. A. (1987). Expression of Xenopus N-CAM RNA in ectoderm is an early response to neural induction. Development 99 , 311-325.

LAEMmLI, U. K. (1970). Cleavage of structural proteins during the assembly of the head of the bacteriophage T4. Nature, Lond. 227, 680-685.

MunTz, L. (1975). Myogenesis in the trunk and leg during development of the tadpole of Xenopus laevis (Daudin 1802). J. Embryol. exp. Morph. 33, 757-774.

NiEuwkoop, P. \& Faber, J. (1967). Normal Tables of Xenopus laevis (Daudin). 2nd ed. Amsterdam: NorthHolland.

Peng, H. B., Markey, D. R., Muhlach, W. L. \& Pollack, E. D. (1987). Development of presynaptic specializations induced by basic polypeptide-coated latex beads in spinal cord cultures. Synapse 1, 10-19.

Peng, H. B. \& Nakajima, Y. (1978). Membrane particle aggregates in innervated and noninnervated cultures of Xenopus embryonic muscle cells. Proc. natn. Acad. Sci. U.S.A. 75, 500-504.

Rieger, F., Grumet, M. \& Edelman, G. M. (1985). NCAM at the vertebrate neuromuscular junction. J. Cell Biol. 101, 285-293.

Rutishauser, U. (1984). Developmental biology of a neural cell adhesion molecule. Nature, Lond. 310, 549-554.

Rutishauser, U., Grumet, M. \& Edelman, G. M. (1983). NCAM mediates initial interaction between spinal cord neurons and muscle cells in culture. J. Cell Biol. 97, 145-152.

Sanes, J. R., Schachner, M. \& Covault, J. (1986). Expression of several adhesive macromolecules $(\mathrm{N}$ CAM, L1, J1, NILE, uvomorulin, laminin, fibronectin, and a heparan sulfate proteoglycan) in embryonic, adult, and denervated adult skeletal muscle. J. Cell Biol. 102, 420-431.

SChWARTZ, L. M. \& KaY, B. K. (1988). Differential expression of the $\mathrm{Ca}^{2+}$-binding protein, parvalbumin, during myogenesis in Xenopus laevis. Devl Biol. (in press).

Sunshine, J., Balak, K., Rutishauser, U. \& Jacobson, M. (1987). Changes in neural cell adhesion molecule (NCAM) structure during vertebrate neural development. Proc. natn. Acad. Sci. U.S.A. 84, 5986-5990.

Thiery, J.-P., Duband, J. L., Rutishauser, U. \& Edelman, G. M. (1982). Cell adhesion molecules in early chicken embryogenesis. Proc. natn. Acad. Sci. U.S.A. 79, 6737-6741.

Tosney, K. W., Watanabe, M., Landmesser, L. \& Rutishauser, U. (1986). The distribution of NCAM in the chick hindlimb during axon outgrowth and synaptogenesis. Devl Biol. 114, 437-452.

Towbin, H., Staehelin, T. \& Gordon, J. (1979). Electrophoretic transfer of proteins from polyacrylamide gels to nitrocellulose sheets: procedure and some applications. Proc. natn. Acad. Sci. U.S.A. 76, 4350-4354.

Watanabe, M., Frelinger, A. L., III \& Rutishauser, U. (1986). Topography of N-CAM structural and functional determinants. I. Classification of monoclonal antibody epitopes. J. Cell Biol. 103, 1721-1727.

(Accepted 31 March 1988) 